\title{
Theodoros Terzopoulos' Promethiade (2010), or the Revolutionary Power of Contemporary Theatre
}

\author{
Em. Freddy DECREUS \\ Ghent University
}

\section{Introduction}

The mythological figure of Prometheus, bringer of civilisation and creator of culture, liberator and benefactor of men, expresses an archetypal way of thinking that characterizes well western civilisations. Both as a culture hero who changed the world through the discovery of fire and as a strickster who stole the fire from the gods to give it to the humans, he played a fundamental part in the way a whole continent conceived and expressed its position towards the divine. He inspired artists and philosophers for more than 3000 years, rendering their longings for independence, artistic inventivity and scientific imagination. Last year, he was chosen as leading figure in an international cultural project that once again revealed how deeply he was rooted in a shared culture, but also how easily he could serve intercultural purposes.

The Promethiade was a major cultural event that brought together three countries in the framework of the Capitals of Europe 2010, featuring Athene (Eleusis), Istanbul and Essen. Three different cities and cultures were gathered and united during a couple of months, on three important festivals, staging productions on a series of really unique locations, in three different spectacular settings created by the famous Greek arte povera artist Jannis Kounellis: the festival of Athens with productions in the Herodes Atticus Odeon and in an old Oil-Mill Factory in Eleusis (7 to 15 July), a second one in Istanbul (in the Byzantine churchyard of the Hagia Eirene, from 18 to 28 July) and finally a third one in the area of the Ruhr in Essen

Classical Papers, vol. xi , 2012 


\section{- Theodoros Terzopoulos' Promethiade (2010), or the Revolutionary Power of Contemporary Theatre}

(Zollverein, from 23 July to 7 August). Three totally different artistic and cultural challenges resulted in important political and artistic statements, with directors and actors coming from three different countries (Greece, Turkey and Germany), presenting bilingual and thrilingual productions.

Three completely original performances of Prometheus were conceived and produced by Theodoros Terzopoulos (Prometheus Bound, played in Greek, German and Turkish), Sahika Tekand (Vergessen in zehn Schritten. AntiPrometheus, played in German and Turkish), and the Berliner company Rimini Protokoll (Prometheus in Athens, played in Greek and German). These three performances were shown in places that highly were representative for Classical Antiquity, the Middle Ages and Modernity, and, above all, that belonged to the UNESCO World Heritage Project.

\section{Prometheus, reception of a mythic hero}

Prometheus, one of the first heroes to be installed in a western mythological worldview cannot be dismissed so easily, apparently. The theme of the son of the Titan who comes to rescue the earthly, material and mortal humans, remains, after all these centuries, a very welcome theme in the interpretation of what is means to be 'human'. He is the centre of a myth that easily transcends cultural boundaries, a tragic hero who, for the benefit of humanity, fights authorities that belonged to his own bloodline, someone who is at the dawn of several Enlightenments with all their philosophical, ethical and political problems. He is a figure of the imagination who was created to set into motion a process of a tremendous human dynamics that continues to go on until today, but always was inscribed in a double programme. On the one hand, his character definitely sounds progressive and even optimistic, since he was the creator of man from clay, one who stole fire for them and provided them with wealth and progress, but on the other this myth also knew a regressive pattern, since it announced future punishment, disaster and decay. To put it into Jungian terms, he is the continuous Shadow who accompanies the fate of man as he is performing his quest for Individuation. However, as Frank Raddatz mentions, he also is 


\section{Em. Freddy DECREUS}

'this first engineer of cultural techniques (who) heads the era of unabated growth that is reaching its planetary limits today' and therefore '(I)t is particularly indispensable nowadays, in a period marked by an emerging resources shortage and global climate change, to question the essence of the Promethean anew (2011: 12). Precisely because man has to mould his imagination into stories, in order to survive and escape the horror that reigns the absolute character of reality he is bound to continue inventing images about both the way he is trapped in and secured by reality. Many contemporary adaptations question what has become of the 'liberator of humanity' in the technological and dehumanized times we are living in. As many studies made clear, every age projected into his mythological mask the kind of answers and questions that were important at that very moment (Trousson, 1964) and our decade behaves not differently.

In the Christian imagination, Prometheus was destined to resemble Christ, since both of them were famous for the way they loved humanity, and sometimes he even was evoked to figure like the revolutionary Lucifer (Werblovsky, 1952). He was the favourite artist of Goethe's Age of Enlightenment (1789), was used as a model in Mary Shelley's threatening Frankenstein (1818), was represented as the 'the noblest saint and martyr in the philosophic calendar' of Karl Marx (1841) and provided a modernist parody in André Gide's Le Prométhée mal enchaîné (1899). Closer to our times, he was the main subject in 'Die Befreiung des Prometheus', a text that was part of 'Zement' (1972) by Heiner Müller. The old hero was made famous in a grotesque way in the performance of the same name by Heiner Goebbels, first as a radio play in 1985 (awarded many prices) and later on adapted for theatre. This play travelled in different countries with Müller himself and was staged with a lot of local actors. In 1991, an actress from the Athenian Attis theatre, Sofia Michopoulou, staged a lecture of this play with Heiner Müller himself (in the form of a radio play). In 1995 (premiered in Montalcino, Toscana) Terzopoulos with his group created a new version of Prometheus Bound and travelled around the world with it (from 1995-2003). The Prometheus Bound that he made now for the theatre 


\section{- Theodoros Terzopoulos' Promethiade (2010), or the Revolutionary Power of Contemporary Theatre}

festivals 2010 in a trilingual version again was an entirely new performance, as political as the previous versions that were influenced by Heiner Müller (for instance, see his Medea Material (from 1988 on), Quartet (from 1989) and several adaptations from Heracles (1997) (for a detailed playlist of all of Terzopoulos's productions, see: Sampatakakis, 2007).

\section{Theodoros Terzopoulos, Prometheus Bound (2010)}

Theodoros Terzopoulos was born in the village of Makrigialos in northern Greece, the mythical birthplace of Euripides. In 1986, he founded the Attis theatre in Athens, one of the most original experimental theatre companies in Greece. From 1985 to 1987, he was the artistic director in Delphi of the Greek Drama International Meetings organized by the European Cultural Centre of Delphi. In 1990 he was a founding member of the International Institute of the Mediterranean Theatre comprising 22 Mediterranean countries. Since 1993, he was the Chairman of the International Committee of the Theatre Olympics. In 1999 he chaired the 2nd Theatre Olympics held in Shizuoka, Japan, and in 2001 he was the chairman of the Theatre Olympics in Moscow. His most successful productions (Bacchai, 1986; Medeamaterial, 1988; Perses, 1990; 2003; Ajax, 2004,... ) were awarded many prices and toured around the world for many years. Last year, a colloquium organised by Erika Fischer-Lichte at the Freie Universität Berlin, was dedicated to his provocative theatrical career (Dionysus in Exile The Theatre of Theodoros Terzopoulos, 23 - 24 September 2011, at the ' Griechische Kulturstiftung Berlin').

Theodoros Terzopoulos belongs to that small group of worldwide famous directors who elaborate their own theatrical language and who introduce it in many countries worldwide. The last years, his methodology has been described in a number of books published in different languages (an., 2000; Raddatz, 2006; Sampatakakis, 2007; Hatzidimitriou, 2010; Karaboga, 2008) and presented to a lot of international audiences in the USA, Russia, China, Japan, Argentina, ... Recently, even a Chinese and a Russian book 


\section{Em. Freddy DECREUS}

was dedicated to him: ТРАГЕДИИ, «БаЛТИЙСКе СеЗОНЫ», St Petersburg 2009 and Theodoros Terzopoulos, China Theater Press, Beijing 2011. He started his career as a political refugee who escaped the Greek military dictatorship and was welcomed in East Berlin, where he worked as an assistant dramaturge at the Berliner Ensemble, a theatre where he became friends with Heiner Müller and was schooled in Brechtian dramatics (1972-1976). He adopted the techniques of the Verfremdungstheater and after returning home to Greece, where he became the artistic director of the National Theatre of Northern Greece (19811983), he applied these principles to a number of well known classics (Medeamaterial, 1988; Quartet, 1989; Persians, 1990; Antigone, 1994,...). During his stay in Germany, he started to look at Greek culture from a different point of view, an experience that brought him back to the foundations of Greek myth and tragedy. In 1986 he founded in Athens the Attis theatre and developed a specific theatrical method that brought him international recognition and glory, often in close collaboration with his Japanese compeer Tadashi Suzuki. The strong physical staging of his Bacchai (1986) meant a shock to traditional Greek nationalism, turning him for a long time into the 'bête noire' of Greek theatre criticism, but these local incidents did not prevent him from touring around the world with this tragedy.

Most of his productions contain a clear political commentary (see for instance his Bremer Freiheit from R. W. Fassbinder, 1989, or Money from Bertold Brecht, 1998) and are constantly looking for actual relevance and importance for contemporary people. He defends issues about human rights, economy and progress, and is always concerned about human suffering in its many forms. In fact, Greek tragedy served a double purpose to him, since it was handled both as a model for political and ideological analysis and for renewing established Western aesthetics. In the most general sense, his political agenda always has been based on a reassessment of the in depth-structure of Greek tragic theatre. Since mythic Attis himself has been victimized in order to rise and shine in a later period of the year, 


\section{- Theodoros Terzopoulos' Promethiade (2010), or the Revolutionary Power of Contemporary Theatre}

tragedy for Terzopoulos always refers to the Dionysian myth that thrives upon the phenomena of life and death, of destruction of the cosmic order and its renewal, of catastrophe (sparagmos) and its reconstruction. However, these mythic materials ultimately lead to further questions and helped to analyse historical and ontological dimensions of men, mostly in their insatiable thirst for bloodshed and atrocity.

Three important questions will be discussed now, following the three major dimensions in Terzopoulos' work, the political, the cultural and the aesthetic, and they will give rise to a number of issues that are at the heart of contemporary philosophy and ideology.

\subsection{The political argument}

First of all, there is the interpretation of Prometheus given by the director himself. Looking at the scenery of the three locations where this play has been produced (Elefsina, Istanbul and Essen) it must be clear that the Prometheus Bound does not bring an optimistic message. An old industrial Oil Mill Factory in Elefsina, an orchestra made up by 50.000 pair of glasses in Istanbul and two trains referring to migration and deportation in Essen, ... not at all the most happy memories one can imagine when the bringer of civilisation by excellence is about to be staged! In Elefsina, the Athenian harbour, a dark and polluted version of the luminous and luxurious Piraeus, also the place where in the past a temple of resurrection dedicated to the goddess of the grain, Demeter and her daughter Persephone, brought together spiritual searchers for inner peace and regeneration, one could not escape the idea of a generalized Fall, of a Greek hero who irrevocably fell down, of a civilisation that came to its end. Yannis Kounellis' gallery of stones enrobed the whole facade of the collapsing Oil Mill and definitely created an atmosphere of anxiety and captivity. A universal prison surrounded by alarming sirens before, during and after the play evoked a pandemonium that fitted well the old story. During one of the greatest financial and economic crises Europe, and Greece especially, have known, this was the place where the Great Capital could be targeted, where 


\section{Em. Freddy DECREUS}

shipowners and banking magnates, the new Olympic generation, kept their distance, as contemporary gods, not caring at all for the fate of the mortals. They were addressed by the repeated remark of the chorus: 'the day will come, der Tag will kommen', a revolutionary appeal that clearly referred to Heiner Müller.

As Terzopoulos mentions himself:

'It is perhaps less a thesis than an expression of hope for the despairing who demand a new awareness. To establish new ways of thinking, one must return to the beginnings and rethink everything from the outset. The teleological line into our time appears to be cut off. This is an end like in Beckett's work. But the only question that exists today is: what does a new beginning look like? Certainly, this new beginning does not arise from the negation of negation, as Hegel's formula suggests. But when the absolute end is reached, the issue of a real new start emerges that is no longer part of the process. How can we leave the process? Only that would be a new beginning. However, we do not know what this other start looks like. Brecht still thought he knew what this start looked like, but today this knowledge is no longer sufficient' (2011: 96).

In his Prologue to the book following directly the production and edited by Frank Raddatz (May 2011), this author remembers that the main problem of Modernity already was discussed in the 1940s.

'In the 1940s, when the heads of the Frankfurt School, Theodor W. Adorno and Max Horkheimer, formulated their theses on the dialectic of enlightenment in their American exile, not only people with a strong historical-philosophical background were aware that something has gone wrong with the mega-project "enlightenment", the effort to create a rational arrangement for human coexistence' (2011: 13).

Quite opposite to the many optimistic and humanistic forms of imagination that turned Prometheus into a positive hero, this 2010 prototype stands on a dangerous edge. The old order is collapsing and hope can only be restored through discontinuity of the system. This new Prometheus is more than ever an anarchic one, someone who envisions a break in western history, a 


\section{- Theodoros Terzopoulos' Promethiade (2010), or the Revolutionary Power of Contemporary Theatre}

point of no return conceived by a disappointed subject who cannot any longer align past, present and future. This culture hero even urgently invites us to reconsider our attitude towards the future and to think at what costs and risks we embraced the technological development. It is the historical edge already evoked in Paul Klee's ambiguous 'Angel of History', Angelus Novus painted in 1920, an angel locally flying in the air, eyes and mouth wide open, the wings spread, the face pointed to the past.

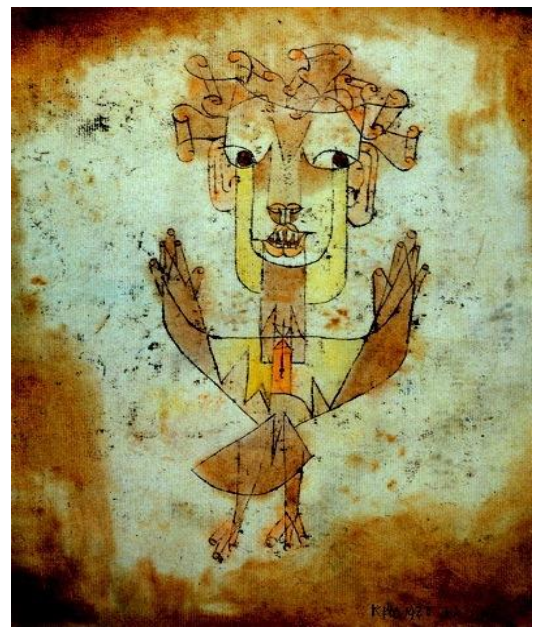

Here one remembers how Walter Benjamin described this nightmarish figure in his essay 'On the Concept of History' (Über den Begriff der Geschichte. These IX, 1940):

'An angel is depicted there who looks as though he were about to distance himself from something which he is staring at. His eyes are opened wide, his mouth stands open and his wings are outstretched. The Angel of History must look just so. His face is turned towards the past. Where we see the appearance of a chain of events, he sees one single catastrophe, which unceasingly piles rubble on top of rubble and hurls it before his feet. He would like to pause for a moment so fair [verweilen: a reference to Goethe's Faust], to awaken the dead and to piece together what has been smashed. But a storm is blowing from Paradise, it has caught itself up in his wings and is so strong that the Angel can no longer close them. The storm drives him 


\section{Em. Freddy DECREUS}

irresistibly into the future, to which his back is turned, while the rubble-heap before him grows sky-high. That which we call progress, is this storm'.

\subsection{The (inter)cultural argument}

The Promethiade, as one of the new forms of art and communication created by a new global world politics, no doubt raises the question of the value and function of an intercultural project. Traditional borderlines, nations and spaces evaporate, mental and geographical distances shrink and new types of cultural awareness become necessary. As a study on the falling subject, Theodoros Terzopoulos' Prometheus figures among those who wonder where our type of civilisation came from, what were its mythic and religious origins, and what were the costs and benefits of their creation. More than ever, our times developed a curiosity for 'the making of cultures' and their characteristic differences. Some years ago, in 1996, Samuel P. Huntington (sponsored or not by the CIA) published a book on the 'Clash of Civilisations' and relied heavily on cultural and religious presuppositions. These are the times when one discovers that there is more than just one type of civilisation, religion and culture, no longer one dominating race or nation, no longer one type of mythological imagination or anthropological theory about the origins and the birth of man. Organizing international events like the Promethiade where the interaction of different worldviews and imaginations was stimulated always is an important exercise in what we call now 'interculturalism'. How do cultures really relate to each other, and how do we see such a complex thing as a 'culture'. Of course, we no

longer understand culture in terms of what Matthew Arnold defined as 'the best that has been thought and said', but the latest generations gradually opted for the recognition of a more conflictual and hybrid nature of the notion of culture itself, along the lines of Werner Hamacher's definition of culture as 'culture's shame for perhaps not being sufficiently culture' (1997:295). 


\section{- Theodoros Terzopoulos' Promethiade (2010), or the Revolutionary Power of Contemporary Theatre}

This is the reason why this production needed to be staged in three different languages, since the birth of the new international and intercultural 'market' invites us to talk and listen to many languages. On a concrete level, the consequence was that the production, as it has been staged in three countries, involved a lot of textual fragments that remained untranslated and hence were incomprehensible to the local public. In Eleusina, Greeks did not understand the great portions spoken of Turkish, in Istanbul the knowledge of Greek will not have be terrible (though maybe possible), in Essen the possibility existed that the Turkish community came to attend their actors, but, in general, feelings of estrangement and displacement must have overcome all spectators. However, listening to each others intonation, rhythms, (body) languages, whispers and cries surely was a very good exercise in becoming global citizens.

Prometheus always was a mythic character that reminded us of the creation and the preparation of a dawn of a new era. He is one of the standard characters (comparable to many others in other cultures, mythologies and religions) that models and conditions the birth of a certain type of civilisation, suggesting the possibility of contesting older generations of gods and reminding us of the dynamic (titanic) force that inhabits such a contestation. He is the one who knows secrets that the generation of the younger Olympians are not aware of, and in providing the fire to the humans he breaks down some of the ontological arguments and conditions the older gods are made of. This mythological and religious position came to us in the form of a narrative that talked about our own origins and our capacity to deal with the titanic force in ourselves. Clearly, gods never exists in real, they are only symbolic frames that ask for an interpretation by the humans who, by their very nature, are in a desperate need for heroes situated outside the human race itself. Prometheus is situated on a symbolic place in between men and gods, tied up at one of the highest points of nature (mount Caucasus, a typical place for both epistemological categories to meet), the arms spread out like an eagle, willing but not able to fly, a complex symbolic being that in so many ways expresses the human desire 


\section{Em. Freddy DECREUS}

to transcend our banal and modal constitution. In the eyes of Terzopoulos, a being like Prometheus expresses an important part of our existential battle, caught as he is in a mortal body: 'Wir haben einen permanenten Konflikt im selben Körper. Das ist Prometheus. Das ist die hauptsächliche Idee von Prometheus'. Staging, each generation again, this key character of the western imagination, situates us along the lines of what Hans Blumenberg has delineated in his remarkable book Work on Myth (1996, Arbeit am Mythos, 1988). As humans we are obliged to continue this symbolizing process, he said, simply because we cannot escape the existential position of a human who is bound to face the 'Absolutism of Reality'. We constantly fall back upon the imagery of our first contemplations and the first absolute metaphors we developed (light vs. darkness; high vs. low; hence light as truth).

In the eyes of Terzopoulos it takes courage to reconsider the absolute metaphors we still use today as well as the historical and mythological roots that are responsible for the way we think, feel, love and fight, and to integrate them into a new globalised and intercultural field, into the new ethnic, national and cultural borders, because interculturality determines more and more the new face of Europe, and therefore also of its production of art, religion and worldviews. Or, in the repeated words of the actress Sofia Michopoulou, playing the part of the Old Woman: 'Otan tha' cho pethanei, o kosmos th'allaksei' / 'When I will die, the world will change'.

True interculturalism goes beyond the easy clichés and stereotypes (Said, 1978) and calls for comparative research concerning each others basic imaginations, esp. concerning the foundational stories of our worldviews and religions. This basic attitude asks for courage, since it evolves on the edge itself of what cultures and religions allow us to think and to imagine (see the Salman Rushdie 'affair').

\subsection{The (post) tragic discussion}

Part of the basic imagination of the West has always been its tendency to explore the tragic dimension in life. Human life is tragic, the Greek poets 


\section{- Theodoros Terzopoulos' Promethiade (2010), or the Revolutionary Power of Contemporary Theatre}

said (in fact from Homer on), and the Athenian fifth century fully explored the philosophic and dramatic consequences of such a hypothesis. Ever since, the Western imagination has been haunted by this poetic and existential flavour and the history of the West cannot be conceived outside this sensibility. Since this issue apparently has been felt as culturally important, a very high place has been attributed to tragedy in the hierarchy of literary genres. The will to act and interfere into nature constitutes one of the trademarks and mythical deep structures of the kind of civilisation we have made for ourselves and which, conversely, turned us into the cultural beings that we actually are. Eastern worldviews, such as Buddhism or Hinduism, from the very start developed a totally different cosmogonic, mythological and philosophical view of nature and our relation to it and did not display the kind of ontological Self that became fashionable very early in the Western tradition. However, recently attention was drawn to the discontinuities of this tragic feeling in the making of the West. In George Steiner's opinion (1961), we are living the 'Death of Tragedy' since technological times provided us with other solutions. On the other hand, Camille Paglia never got tired mentioning that the tragic hypothesis relied upon a typically male gaze and construction (1990:7). In her own words:

'Tragedy is a male paradigm of rise and fall, a graph in which dramatic and sexual climax are in shadowy analogy... Traditional eastern stories are picaresque, horizontal chains of incident. There is little suspense or sense of an ending.... Western dramatic climax was produced by the agon of male will. Through action to identity' (1990: 6-7).

Defining the tragic dimensions, it is also a good occasion to remember its historical embodiment and think about the great differences that charcterized each tragic period, as William Storm mentioned (1998: 32):

'The truism persists that tragedy has truly flourished in only four historical epochs: the fifth century B.C. in Greece; the Renaissance, particularly in Britain; France in the late seventeenth century; and Europe in the late nineteenth and early twentieth centuries. These 


\section{Em. Freddy DECREUS}

periods, in and of themselves, have become the instruments of measurement and comparison'.

Many critics situate the production of contemporary tragedies within a postdramatic (Lehmann, 1999) and post-tragic climate. As I mentioned before in an article called 'About Western man and the "gap" that is constantly threatening him. Or how to deal with the tragic when staging Greek tragedies today?', the problems start with the perception of myth itself:

'Since traditional myth is moth-eaten and its fragmented parts do not function any longer in a homogenized framework which is able to provoke a real confrontation, the present situation often only provokes post-tragic feelings and inspires a generalized atmosphere of tragic awareness which completely lacks an exit, evoking a silence before a storm which probably is never going to take place. Because exemplary cultural reflections are lacking, because general aims are unclear (and, if present, in the hands of an anonymous international capital) and because art rather helplessly opposes art (becoming commerce and entertainment), culture has turned into 'trial and error', ready to be taken over by new ideologies which promise to put everything in order, thus creating a situation which will brush away all tragic thinking (Botho Strauss, Anschwellender Bocksgesang, 1993; Ithaka, 1996) (2003: 76).

Today we clearly recognize the founding categories of our existential way of thinking and living. Seen from a deconstructive angle, the tragic condition is mainly a pair of glasses needed to have a particular vision on 'reality', creating a particular flavour and appreciation of live. Tragedy is not a soteriological construction (unlike the three western book-religions), it is man-made, diverse in its historical periodization, and today questioned in its post-tragic characteristics.

At the end of Terzopoulos' Prometheus, all actors burst out in a long and thundering laughter, as they did in the beginning and at the end of a previous production Aias (2004), in the words of the director, a situation of 'klausigelos', a process of laughing and crying at the same time, much more impressive than laughing and crying separately, a phenomenon that asks 


\section{- Theodoros Terzopoulos' Promethiade (2010), or the Revolutionary Power of Contemporary Theatre}

whether or not tragedy is still able to encompass all of this today? It is sarcasm that lives here in this tragic situation. Are these the dominant feelings that overcome contemporary societies? Is this a consequence of technological sophistication and economic degradation? What happened to the human dreams fostered in days of the Enlightenment, the ones about permanent progress for everyone? Did not many of them turned out into atypical or even antitypical forms of humanism and did they not provoke a deep situation of the ludicrious ('Lächerlichkeit') about 'la condition humaine'? All of these are questions that are of the deepest concern to the director all through his life, questions that he likes to discuss each time again in new forms. In his own words:

'All that remains now is sarcasm. Laughter. The dramatic or tragic dimensions are dissolved. We are in a post-tragic space. This means we are constantly make mistakes. We are a machine full of errors. Of the promises of progress, nothing has been left. This is a post-tragic vision. It's not like it used to be in the myth where the God says: You are my marionette and I'm blinding you to make you commit a mistake'... Therefore, he says, '(T)his is the absolute end, this darkness must be shown by art. This uncertain darkness is the future.... The great emotion that arose from the de-constructed bodies of the actors evoked a vague, indefinite and ontological grief. The actors of the performance and the audience found themselves in an alarming situation, as a reaction to the injustices, the abominable crimes that were committed by the so-called "mediums of law" and their relentless verdicts. We must accept the evil and make people aware of it instead of speaking on behalf of a utopia. (2010: 96; 98).

\section{Conclusions}

The 2010 International Theatre Festival fostered by three different nations focused on the Promethiade and raised some annoying but very interesting points. This Festival asked some difficult questions about the place of Western history and the notions of Progress and Enlightenment. However, this was not just a production that fell out of the sky, but was thoroughly prepared since the day that, in 1986, an exile and expatriate got the opportunity to question his own culture and systematically introduced 


\section{Em. Freddy DECREUS}

Brecht and Müller in the Greek theatrical landscape. The 2010 productions provided an answer to the archetypical mythical hero Prometheus and the kind of aspirations he introduced, from the start, into western sensibilities. Terzopoulos' specific body language ending up in a endless 'klausigelos', Shahika Tekand's technical genius and plaidoyer for a stronger feminine presence, as well as the sociological questions asked by Rimini-Protokoll, revealed different answers to contemporary problems on so many levels. George Sampatakakis, author of many articles and books on Theodoros Terzopoulos' practice, recapitulated the main issues as follows:

'Terzopoulos' Prometheus in Elefsina was an aggressive manifesto for a civilization in crisis. Prometheus' revolt is a historic paradigm that we should rethink dialectically. WE EITHER RISE, OR ALL FALL DOWN' (2011:117);

\section{Bibliography:}

(An.), Theodoros Terzopoulos and The Attis Theatre. History, Methodology and Comments, Athens, 2000, Agra Publications.

Hans Blumenberg, Work on Myth, Cambridge Mass./ London, 1990, MIT Press (1979)

Penelope Chatzedemetriou, Theodoros Terzopoulos: Apo to Prosopiko Sto Pagkosmio, Thessaloniki, 2010, University Studio Press.

Freddy Decreus, 'La tragédie classique et sa mise en scène moderne', in: Euphrosyne 26, 1998, pp. 331-346.

Freddy Decreus, 'About Western man and the "gap" that is constantly threatening him. Or how to deal with the tragic when staging Greek tragedies today'?, in: Euphrosyne 31, 2003, pp. 61-82.

Freddy Decreus, 'Die Kunst des Singens in der "Vorkammer des Todes" / The Art of Singing in the "Antechamber of Death" ', in: Raddatz, 2006, pp. 202-213.

Freddy Decreus \& Mieke Kolk (Eds.), Rereading Classics in 'East' and 'West'. Postcolonial Perspectives on the Tragic, in: Documenta XXII, 2004, 4, pp. 255-426.

Werner Hamacher, 'One 2 Many Multiculturalisms', in: Hent De Vries \& Samuel Weber (Eds.), Violence, Identity and Self-Determination, Stanford, 1997, p. $295 \mathrm{ff}$. 
- Theodoros Terzopoulos' Promethiade (2010), or the Revolutionary Power of Contemporary Theatre

Kerem Karaboğa, Tragedya ile Sinırları Aşmak - Theodoros Terzopoulos'un Tiyatrosu, Dizisi, 2008, Yayinlari.

Hans-Thies Lehmann, Postdramatische Theater, Frankfurt, 1999, Verlag der Autoren

Hans-Thies Lehmann, 'Terzopoulos' Müller - Eine Skizze', in: Raddatz, 2006, pp. 176-185.

Camille Paglia, Sexual Personae: Art and Decadence from Nefertiti to Emily Dickinson, Yale and London, 1990, Penguin Books.

Frank Raddatz (Ed.), Reise mit Dionysos: Das Theater des Theodoros Terzopoulos / Journey with Dionysos : The Theatre of Theodoros Terzopoulos, Berlin, 2006, Theater der Zeit.

Frank Raddatz, Im Labyrinth. Theodors Terzopoulos begegnet Heiner Müller, Berlin, 2009, Theater der Zeit, Recherchen 56.

Frank Raddatz (Ed.), Athens Istanbul Essen 2010 Promethiade, Essen, 2010, Klartext-Verlag, 231p.

Frank Raddatz, Promethiade Prologue, in: Raddatz, 2010, pp. 10-15.

Frank Raddatz \& Theodoros Terzopoulos, 'Theodoros Terzopoulos in Conversation with Frank Raddatz', in: Raddatz, 2010, pp. 96-109.

Edward Said, Orientalism. Western Conceptions of the Orient, New York, 1978, Pantheon Books.

George Sampatakakis, 'Dionysos Restitutus - Terzopoulos' Bakchen' / 'Dionysos Restitutus - The Bacchae of Terzopoulos', in: Reise mit Dionysos: Das Theater des Theodoros Terzopoulos / Jpurney with Dionysos : The Theatre of Theodoros Terzopoulos, Ed. Frank Raddatz, Berlin, 2006, Theater der Zeit, pp. 90-102.

George Sampatakakis, Geometrontas to Chaos: Morphe kai Metaphysike sto Theatro tou Theodorou Terzopoulou, Athena, 2007, Metaichmio.

George Sampatakakis, 'Codex Prometheus', in: Raddatz, 2011, pp. 116-117. George Steiner, La mort de la tragédie, Paris, 1961, Seuil.

William Storm, After Dionysus: A Theory of the Tragic, Ithaca \& London, 1998, Cornell UP

Raymond Trousson, Le thème de Prométhée dans la littérature européenne, Genève, 1964, Droz.

Raphael Jehudah Zwi Werblowsky, Lucifer and Prometheus: A Study of Milton's Satan. Routledge, 1952. 